Warren Mayo MD FRCPC, Kenneth Leighton MB FRCPC, Barbara Robertson MD FRCPC, John Ruedy MD FRCPC

\title{
Intraoperative cyanosis: a case of dapsone-induced methaemoglobinaemia
}

Intraoperarive cyanosis is most commonly caused by hypoxaemia. The anaesthetist is requirel io perform a rapid series of diagnosic manoeuvres and take remedial action. Occasionally methaemoglobin, sulfhaemoglobin, or haemoglobin $M$ undetected preoperatively, is the cause of the cyanosis. We report a case of methaemoglobinaemio sfromdary to dapsone ingestion that was diagnosed intraoperativety. Dapsone, a stilfone, is used therapeutically to treat leprosy and dermatitis herpetiformis. The differential diagnosis of cyanosis, and the origin and fate of methamoglobin are discussed. In addition the diagnostic steps and the laboratory investigations required to make the diagnosis are listed.

Cyanosis is a sign for which the anaesthetist must be alert. Intraoperative cyanosis requires rapid and definitive diagnostic manoeuvres to rule out hypoxaemia prior to considering mote exotic causes. The following case illustrates the course of such an investigation.

\section{Case report}

A 15-year-old boy from France, while attending an international church conference, developed periumbilical pain. After 48 hours the pain localized to the right lower quadrant and he was taken late at night to the emergency department. A diagnosis of appendicitis was made. Intravenous fluids were started and he was given metronidazole $500 \mathrm{mg}$, tobramycin $60 \mathrm{mg}$, meperidine $50 \mathrm{mg}$ and dimenhydrinate $50 \mathrm{mg}$

The patient gave a history of essential hypertension and

\section{Key words}

COMPLICATIONS: cyanosis; BLOOD: methaemoglobinaemia; ANAESTHETIC TECHNiQUES: general; PHARMACOLOGY: dapSONE.

From the Department of Anaesthesia, Health Sciences Cenire, University of British Columbia, and the Department of Medicine, St. Paul's Hospital, Vancouver, British Columbia.

Address correspondence to. Dr. Warren Mayw, Department of Medicine, St. Paul's Hospital, 1081 Burrard Street, Vancouver, British Columbia V6Z IY6. cigarette smoking. Allergies and the ingestion of any drug prior to admission were denied by the patient and his father.

Physical exam revealed a well hydrated 15 -year-old boy whose skin appeared somewhat grey, with a BP of $180 / 70$, a pulse of 96 and a temperature of $38.0^{\circ} \mathrm{C}$ Abdominal examination was consistent with a diagnosis of acute appendicitis. The respiratory and cardiovaseular systems were normal. The laboratory data were $\mathrm{Hb}$ $15.0 \mathrm{~g} \cdot \mathrm{dl}^{-1}$, WBC $15.2 \times 10^{3} / \mathrm{dl}$, polymorphonuclear leukocytes $13.9 \times 10^{3} / \mathrm{dl}$ with the serum electrolytes, BUN and creatinine all within normal limits.

The patient was brought to the operating room and prior to induction he received $\mathrm{d}$-tubocurare $3 \mathrm{mg}$ and fentanyl $100 \mu \mathrm{g}$. A rapid-sequence induction technique was used. Following pre-axygenation he was given thiopentone $250 \mathrm{mg}$ and succinylcholine $100 \mathrm{mg}$. Anaesthesia was maintained with isoflurane one per cent, nitrous oxide 66 per cent, oxygen 33 per cent, and fentanyl $150 \mu \mathrm{g}$. At the time of intubation there was an increase in BP to $185 / 90$ and pulse to 125 but these soon became steady at $\mathrm{BP}$ $130 / 80$ pulse 80 . The ventilator settings were: tidal volume $800 \mathrm{ml}$, rate nine per minute, with a peak inspiratory pressure of $14 \mathrm{~cm} \mathrm{H}_{2} \mathrm{O}$.

Following incision of the skin the surgeon commented that the blood was "blue." The patient was then ventilated manually. The $\mathrm{FIO}_{2}$ was increased to 1.0 . The chest was ausculated and its movement observed. The correct position of the tube in the larynx was confirmed visually. The oxygen analyzer confirmed that 100 per cent oxygen was being delivered. The BP and pulse were unchanged. Arterial blood drawn for gas analysis was chocolate brown, with $\mathrm{pH} 739, \mathrm{PaCO}_{2} 37 \mathrm{mmHg}$ and $\mathrm{PaO}_{2}$ $438 \mathrm{mmHg}$. A tentative clinical diagnosis of methaemoglobinaemia was made. The appendectomy continued uneventfully, with an $\mathrm{FIO}_{2}$ of 0.5 . Mcthylene blue was not given because the $\mathrm{BP}$ and pulse were stable and the $\mathrm{pH}$ was normal.

The patient had an unremarkable postoperative course. Blood sent intraoperatively revealed methaemoglobin levels of $2.34 \mathrm{~g} \cdot \mathrm{dl}^{-1}$, confirming the clinical diagnosis. Two days later the methaemoglobin level had fallen to $0.32 \mathrm{~g} \cdot \mathrm{dl}^{-1}$. As the methaemoglobin disappeared so did the patient's grey complexion. 
Investigations undertaken postoperatively to determine the cause of the methaemoglobinaemia were: a G6PD screening test, an oxygen dissociation curve, 2,3-DPG levels and NADH reductase levels, all of which were normal. Also no Hb M nor other abnormal haemoglobins were detected by haemoglobin electrophoresis. All three of the patient's siblings had normal methaemoglobin levels.

A supplementary history was taken from the patient and his father. There had been no previous episodes of cyanosis or greyness but eventually the father admitted that the boy had ingested approximately ten "pep pills" (French proprietary medicine containing belladonna) and two $100 \mathrm{mg}$ dapsone tablets the evening prior to admission to hospital. The dapsone had been supplied by a European physician who worked in Africa with the church groups. She had exhausted her supply of sulfa drugs which she normally used to treat diarrhoea and abdominal pain, and had substituted dapsone to treat the young man.

The patient made a satisfactory recovery and was discharged seven days postoperatively.

\section{Discussion}

Cyanosis may be peripheral or central. Peripheral cyanosis is due to reduced flow in the extremities, with subsequent desaturation. It is characteristically seen in the nailbeds and the nose. The arterial blood will be red. Central cyanosis is observed in the mucous membranes of the mouth, the lips and the conjuctiva. The arterial blood will not be red. In the preceding case cyanosis was clearly seen in the operative field in the abdomen.

The differential diagnosis of cyanosis is given in Table I. The most common cause of intraoperative cyanosis is hypoxaemia. Causes of hypoxaemia during anaesthesia are listed in Table II.

It is general ly accepted that cyanosis is apparent in the skin and mucous membranes when there is $5 \mathrm{~g} \cdot \mathrm{dl}^{-1}$ of deoxyhaemoglobin present. ${ }^{1}$ The fact that cyanosis is

TABLE I Differenlial diagnosis of cyanosis

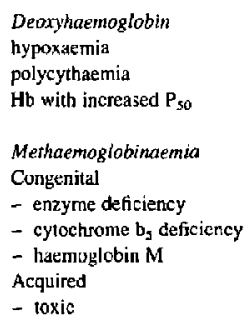

Sulfhaemogiobinaemia
TABLE I] Causes of hypoxaemia during anaesthesia

Reduced PAD

decreased $\mathrm{FiO}_{2}$

decreased alveolas ventilation

Normal $P A O_{2}$

diffusion defect - rare

anatomic shun

ventilation-perfusion inequalities

increased venous desaturation - e.g., decreased cardiac outplt, malignant hyperthermia

neither a sensitive nor a reliable $\operatorname{sign}^{2,3}$ of hypoxaemia does not lessen the anaesthetist's responsibility to determine as rapidly as possible that he is delivering adequate amounts of oxygen to the patient. Very quickly the flowmeters, oxygen monitor and integrity of the circuit can be checked when cyarosis is recognized. The patient should be taken off the ventilator and ventilated manually while checking the spirometer, inspiratory pressures, and observing and aucultating the chest bilaterally. The endotracheal tube's correct position must also be verified. The blood pressure, pulse and tempcraturc of the paticnt should be measured. If all of the preceding investigations are normal, only ventilation-perfusion inequalities, anatomic shunts and diffusion defects remain as possible causes of hypoxaemia. The next step in the investigation is direct measurement of the arterial $\mathrm{PaO}_{2}$.

There are two other causes of deoxyhaemoglobin in excess of $5 \mathrm{~g}^{-\mathrm{dl}^{-1}}$. The first, polycythaemia, can be determined with reference to the patient's preoperative haemnglohin. The second, and much rarer cause, is a low affinity haemoglobin. These haemoglobin mutants have oxygen dissociation curves shifted to the right, e.g., $\mathrm{Hb}$ Kansas has a $\mathrm{P}_{50}$ of 70 . This form of cyanosis should be noticeable preoperatively. ${ }^{4}$

Methaemoglobin is the haemoglobin molecule with the haeme moiety in the oxidized or ferric state. Normally less than $0.15 \mathrm{~g} \cdot \mathrm{dl}^{-1}$ of haemoglobin is in this form and when methaemoglobin levels rise to 1.5 to $2.0 \mathrm{~g} \cdot \mathrm{dl}^{-1}$ cyanosis can be detected clinically. Patients are often described as having a greyish hue and the arterial blood is chocolate brown in colour. ${ }^{4}$ Symptoms do not usually occur until levels are above $4 \mathrm{~g} \cdot \mathrm{dl}^{-1}$.

To prevent accumulation of spontaneously occurring methaemoglobin there are two enzymatic systems in vivo which are capable of reducing the methaemoglobin to haemoglobin:

$1 \mathrm{NADH}$-methaemoglobin reductase. This enzyme transfers an electron from NADH to the haeme using cytochrome $b_{5}$ as an electron carrier (Figure (A)).

2 NADPH-methaemoglobin reductase. This enzyme transfers an electron from NADPH to the haeme but in vivo 
(A)

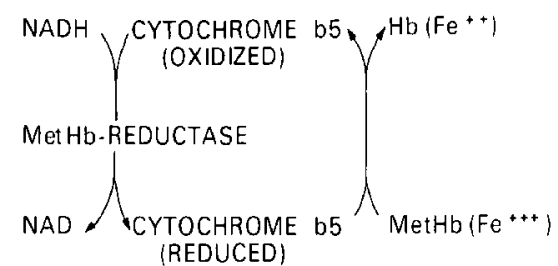

(B)

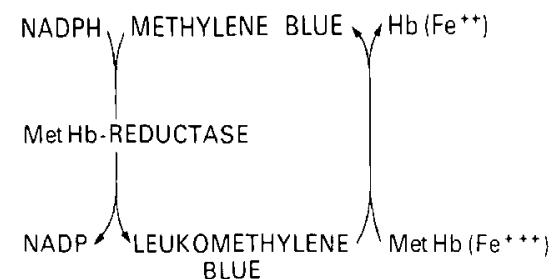

FIGURE Enzymatic systems for the reduction of methaemoglobin to haemoglobin. (A) NADH-methaemoglobin reductase pathway - this pathway is the primary in vivo route for the reduction of methaemoglobin. (B) NADPH-methaemoglobin reductase pathway - this pathway requires an exogenous electron carrier such as methylene blue.

has no electron carrier. If methylene blue is added to the system it acts as an electron carrier and the methaemoglobin is rapidly reduced (Figure (B)).

Patients who are symptomatic with methaemoglobinaemia can be treated with intravenous methylene blue. The initial dose should be $1 \mathrm{mg} \cdot \mathrm{kg}^{-1}$ over five minutes. If no effect is seen in 30 to 60 minutes a repeat dose of $2 \mathrm{mg} \cdot \mathrm{kg}^{-1}$ may be given. NADPH is required as an electron donor for methylene blue to be converted to leukomethylene blue and in turn reduce the methaemoglobin (Figure (B)). Therefore methaemoglobinaemia patients who have a deficiency of glucose-6-phosphate dehydrogenase (G6PD) are unaffected by methylene blue. In addition methylene blue may initiate a haemolytic episode in G6PD-deficient individuals further embarassing their oxygen carrying capacity. ${ }^{14}$

Methaemoglobinaemia causing cyanosis can be either congenital or acquired. Congenital methaemoglobinaemia, which is rare, can be of three forms. A haemoglobinopathy in which an amino acid substitution in the haemoglobin molecule creates an environment in which the haeme molecule is preferentially oxidized. The modified haemoglobin is called haemoglobin M. A deficiency of the NADH-reductase enzyme allowing the accumulation of spontaneously occurring methaemoglobin or the recently described ${ }^{7}$ deficiency of cytochrome $b_{5}$ which cripples the NADH-reductase system by not providing an electron carrier. These patients are described as being more blue than sick. ${ }^{4,8}$

Acquired methaemoglobinaemia is the common form. Many chemical compounds and therapeutic agents are known to directly or indirectly oxidize the haeme moiety. An abbreviated list of the common problem agents is given in Table III. The therapeutic agents commonly incriminated and encountered in anaesthetic practice are prilocaine, benzocaine, amyl nitrite, nitroglycerine, phenacetin and sulfonamides. ${ }^{6,9}$

Dapsone, which appears to have been the cause of the methaemoglobinaemia in this case, is a sulfone used to treat leprosy and dermatitis herpetiformis and is well known to produce a dose related methaemogiobinaemia. The dose administered $(200 \mathrm{mg}$ ) is well above the dose which would produce methaemoglobinaemia. ${ }^{10-13}$

Sulfhaemoglobinaemia is the final cause of cyanosis. It is a green pigmented molecule with a sulfur atom incorporated in the porphyrin ring. It results from irreversible oxidation of haemoglobin by drugs or chemicals. Many of the agents listed in Table III have this potential. It is not understood why reversible methaemoglobin is formed in some instances and irreversible sulfhaemo-

TABLE III Agents implicated in acquired methaemoglobinaemia

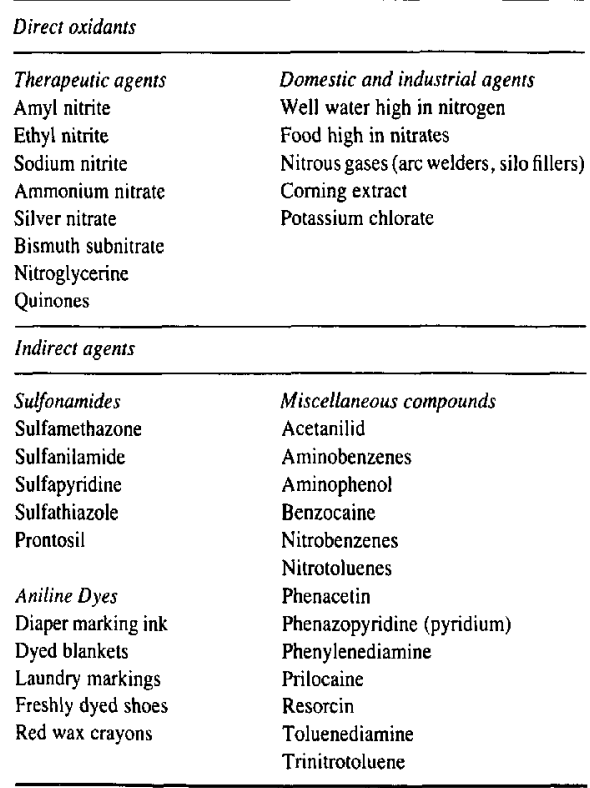


globin in others. Patients with sulfhaemoglobinaemia can be profoundly cyanosed but have minimal dyspnoea. This is because cyanosis can be detected at a blood level of $0.5 \mathrm{~g} \cdot \mathrm{dl}^{-1}$, lower than methaemoglobin $\left(1.5-2.0 \mathrm{~g} \cdot \mathrm{dl}^{-1}\right)$ or deoxyhaemoglobin $\left(5.0 \mathrm{~g} \cdot \mathrm{dl}^{-1}\right),{ }^{4}$ and in addition, sulfhaemoglobin moves the $\mathrm{P}_{50}$ of the oxygen-disocciation curve to the right, enhancing oxygen delivery to the tissues. ${ }^{15}$ The arterial blood is described as having a mauve or lavender hue. ${ }^{4}$

When cyanosis is diagnosed intraoperatively the anacsthetist must act quickly and decisively. A rapid set of manoeuvres must be performed to rule out hypoxaemia. A clear understanding of the differential diagnosis of cyanosis in conjunction with several laboratory tests should then reveal the more exotic causes such as methaemoglobinaemia.

\section{Acknowledgements}

The authors wish to thank the Haematology Department of Vancouver General Hospital for performing the unusual haematological tests and Dr. A. Mangal for his advice and assistance. Also we are greateful for the secretarial help of Ruth Minchington.

\section{References}

1 Lundsgaard C, Van Slyke DD. Cyanosis. Medicine. 1923; 2: $1-76$.

2 Comroe JH, Bothelo S. The unreliability of cyanosis in the recognition of arterial anoxemia. Am J Med Sciences. 1947; 47: $1-6$.

3 Kelman GR. Nunn JF. Clinical recognition of hypoxaemia under fluorescent lamps. Lancet, 1966; 1: 1400-3.

4 Wintrobe MM. Clinical Hematology, 8th edition. Philadelphia: Lea and Febiger, 1981: 1011-20.

$5 \mathrm{Jaffe} E R$. Methemoglobinemia. Clinics in Hematology. 1981; 10: 99-122.

6 Smith RP, Oison $M W$. Drug induced methemoglobinemia. Seminars in Hematology. 1973; 10: 253-68.

7 Hegesh E. Hegesh J, Kaftory A. Congenital methemoglobinemia with a deficiency of cytochrome $b_{5}$. N Engl J Med. 1986; 314: 757-61.

8 Gabel RA, Bunn HF. Hereditary methemoglobinemia as a cause of cyanosis during anesthesia. Anesthesiology. 1974; 40: 516-8.

9 Schmirter $C R$. Sulfhemoglobinemia and methemoglobinemia - uncommon cause of cyanosis. Anesthesiology. 1975; 43: 586-7.

10 Manfredi $G$, De Panfilis $G$, Zampetti M, Allegra $F$. Studies on dapsone induced haemolytic anacmia. $\mathrm{Br} \mathrm{J}$ Derm. 1979; 100; 427-32.

$11 \mathrm{Hjelm} M$, De Verdier $\mathrm{CH}$. Biochemical effects of aromatic amines, I. Methaemoglobinaemia, haemolysis and heinz body formation induced by 4,4-diaminodiphenylsulphone. Biochemical Pharmacology. 1965; 14; 1119-28.

12 Elonen E. Neuvonen PJ, Halmekoski J, Mattila MJ. Acute dapsone intoxication: a case with prolonged symptoms. Clinical Toxicology. 1979; 14; 79-85.

13 Cooke T.IL. Dapsone poisoning. Med J Australia. 1979; $1158-9$.

14 Rosen PI, Johnson C, McGehee W, Beutler E. Failure of methylene blue treatment in toxic methemoglobinemia. Ann Intern Mcd 1971; 75: 83-6.

15 Park CM, Nagel RL. Sulfhemoglobinemia-linical and molecular aspects. N Eng] J Med. 1984; 310: 1579-84.

\section{Résumé}

La cyanose intraopératoire est le plus souvent provoquée par l'hypoxémie. L'anesthésiste est demandé d' accomplir rapidement une série de manoeuvres diagnostiques afin d'y remédier. Occasionnellement la méthémoglobine, la sulfhèmoglobine ou l'hémoglobine $M$, nun délecté en période préopératoire esi la cause de cyanose. On rapporte le cas d' une méthémoglobinémie secondaire à l'ingestion de dapsone ayant élé diagnostiquée en période opératoire. Le dapsone, un suifone, est utilisé afin de traiter la lèpre et la dermatite herpetiforme. Le diagrostic différentiel de la cyanose ainsi que l'origine et le sort de la méthémoglobine sont discutés. En plus les manoeuvres diagnos. tiques et l' investigation du laboratoire requis pour confirmer le diagnostic son énumérées. 